\title{
Species-area relationships in the Hantam-Tanqua-Roggeveld, Succulent Karoo, South Africa
}

\author{
H. van der Merwe ${ }^{*}$ and M.W. van Rooyen \\ Department of Plant Science, University of Pretoria, Pretoria, 0002 \\ ${ }^{*}$ P.O. Box 1, Calvinia, 8190, Republic of South Africa \\ e-mail: soekop@hantam.co.za, Tel/Fax: 0273412578.
}

\begin{abstract}
The Hantam-Tanqua-Roggeveld subregion is part of the Succulent Karoo hotspot of biodiversity which stretches along the southwestern side of South Africa and Namibia. Forty Whittaker plots were surveyed in the spring of 2005 , in eight vegetation associations, to gather diversity data for the Hantam, Tanqua Karoo and Roggeveld areas. Seven plot sizes were used to construct species-area curves using three different models namely: the untransformed linear function, the power function and the exponential function. In general, the power and exponential functions produced a more significant fit to the data than the untransformed linear function.
\end{abstract}

To illustrate the variation in species-area curves and species richness across the landscape, a transect through the study area is discussed. The transect stretches eastwards from the Tanqua Karoo across the escarpment into the Roggeveld and crosses five different vegetation associations. Differences between associations were found in species richness in the $1000 \mathrm{~m}^{2}$ plots. Each association also produced species-area curves with their own characteristics. Slope values for the samples within an association did not differ significantly, although the intercept value often did. Comparisons between associations along the transect revealed significant differences in the slope value between the associations, except for the Dicerothamnus rhinocerotis Mountain Renosterveld which did not differ significantly from the associations bordering it on either side. 
Keywords: biodiversity hotspot, Hantam, Roggeveld, species-area curves, species richness, Tanqua Karoo, Whittaker plots

\section{Introduction}

One of the few laws that has emerged in ecology is that there is an increase in the number of species as the sampled area increases (Tjørve 2003). This pattern was already recognised by De Candolle in 1855 (in Scheiner 2003) and formalised as the species-area curve in the early twentieth century (Scheiner 2003). Recent years have seen a renewed interest in speciesarea curves. In particular it holds promise as a tool in conservation biology (Palmer \& White 1994, Tjørve 2003). Species richness, or the number of species, is currently the most widely used diversity measure (Stirling \& Wilsey 2001) because it is relatively easy to measure, is comparable across communities, and is well understood by researchers, managers, and the public (Hellman \& Fowler 1999). However, species richness per se does not imply any standardisation of sampling area (Whittaker 1977, Whittaker et al. 2001). By adding a spatial scale, species-area curves can provide more information on the nature of the differences between vegetation types in different geographical areas than mere measures of species richness. Amongst other applications, species-area curves have been applied successfully to examine the effects of habitat loss on species diversity (Pimm et al. 1995), the effect of invasions on species diversity (Vitousek et al. 1996) and the identification of hotspots (Veech 2000).

In spite of the seeming simplicity of the relationship between species number and area there are numerous ways to construct species-area curves (Palmer \& White 1994, Tjørve 2003) and an analysis of 100 species-area curves by Connor and McCoy (1979) indicated that there was no single best-fit model. This statement is supported by He and Legendre (1996) whose results suggest that for any particular data set a 'best' model can be constructed but that there is no model that is universally best, and that all depends on sampling scale. 
The Succulent Karoo Biome is a semi-desert region that occupies $111000 \mathrm{~km}^{2}$ on the arid fringes of South Africa's Cape Floristic Region (Mucina et al. 2006). Despite a general lack of structural diversity, plant species diversity at both the local and regional scales in the Succulent Karoo is undoubtedly the highest recorded for any arid region in the world (Cowling et al. 1989). Approximately 30 percent of the world's succulent species are located in this small area (Van Jaarsveld 1987, Smith et al. 1993). On account of its exceptional biodiversity, this region was the first arid land to qualify as a global biodiversity hotspot (Cowling \& HiltonTaylor 1994).

In 2002 the Succulent Karoo Ecosystem Plan (SKEP) was launched to determine the state of biodiversity in this hotspot. For management purposes, the SKEP planning domain subdivided the Succulent Karoo into four subregions, of which the Hantam-TanquaRoggeveld constituted one. However, little information was available on the biodiversity of the subregion that could be used for future planning, conservation and development (Cilliers et al. 2002, Critical Ecosystem Partnership Fund 2003). As the first step to gather botanical information the vegetation associations and subassociations in the subregion were identified, classified and described (Van der Merwe et al. 2008a, 2008b). The next step was to gain information on the ecological properties of each of the vegetation units to improve our understanding, conservation and management of this unique arid area. This paper reports on the analysis of patterns of plant diversity by means of species richness and species-area curves in the Hantam-Tanqua-Roggeveld subregion.

\section{Study area}

The Succulent Karoo stretches along the southwestern side of South Africa and Namibia (Figure 1). The Hantam, Tanqua and Roggeveld areas lie within the predominantly winter rainfall region of the Succulent Karoo in the Northern and Western Cape Provinces of South Africa. Rainfall ranges from $25 \mathrm{~mm}$ per year in parts of the Tanqua Karoo to $467 \mathrm{~mm}$ per year, the annual maximum recorded for Sutherland, on the Roggeveld plateau (Weather Bureau 1998). Although the rain falls mainly in winter it does include a few summer thunderstorms. 


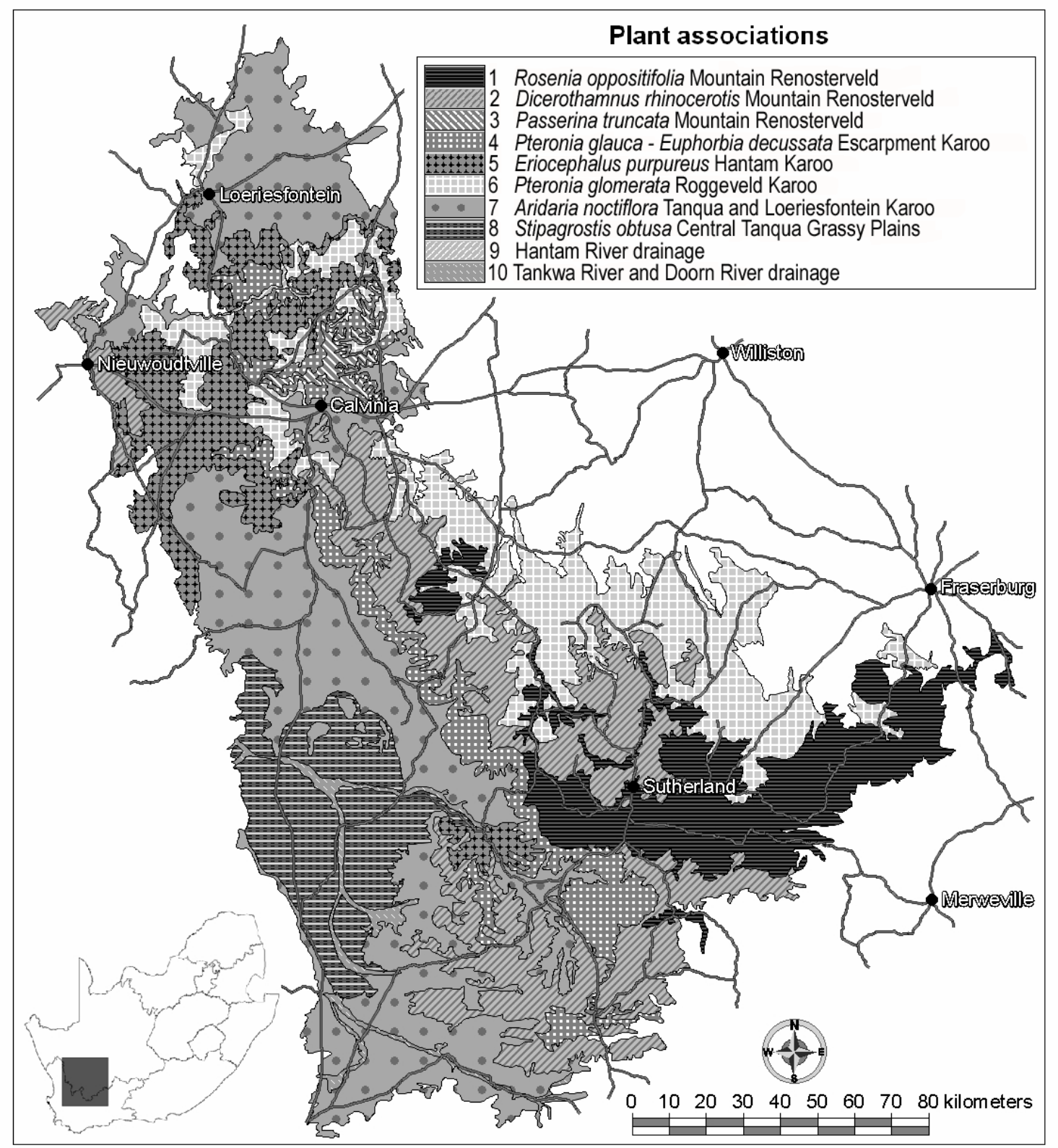

Fig. 1 Location of the eight plant associations identified in the Hantam-Tanqua-Roggeveld subregion of the Succulent Karoo, South Africa (after Van der Merwe et al. 2008a, b). The three Mountain Renosterveld vegetation associations are combined into the Mountain Renosterveld group, the Escarpment Karoo, Hantam Karoo and Roggeveld Karoo are collectively termed Winter Rainfall Karoo and the Tanqua and Loeriesfontein Karoo together with the Central Tanqua Grassy Plains form the Tanqua Karoo vegetation group

The physical geography of the region differs greatly. From the level plains of the Tanqua Karoo the landscape rises steeply to the escarpment formed by the Roggeveld, Komsberg and Nuweveld Mountains, from where it stretches eastwards along the Roggeveld plateau. 
The Hantam is characterised by a gently undulating to a steeply rolling topography. The altitude across the study area varies from approximately $290 \mathrm{~m}$ above sea level in the Tanqua Karoo to about $1800 \mathrm{~m}$ above sea level on the Roggeveld plateau.

The soils of the Tanqua Karoo are shallow lithosols that often include a desert pavement and deep unconsolidated deposits in the alluvial parts. Hantam Karoo soils to the west of Calvinia are composed of shallow lithosols and duplex soils, but where dolerite occurs the soils are red structured and red vertic clays. The mountains of the great escarpment, as well as the Hantam Mountain near Calvinia, are comprised of shallow stony lithosols and duplex soils in the occasional lowlands (Francis et al. 2007).

The study area has a high level of endemism. Hilton-Taylor (1994) identified three centres of endemism namely the Western Mountain Karoo, Roggeveld and Tanqua Karoo within the study area whereas Van Wyk and Smith (2001) recognised the Hantam-Roggeveld as one of the 13 principal regions and centres of plant endemism in southern Africa.

The classification of the vegetation used in this paper follows Van der Merwe et al. (2008a, 2008b) who recently classified and mapped the subregion into eight large vegetation associations and 25 subassociations (Figure 1). These associations are as follows:

1. Rosenia oppositifolia Mountain Renosterveld,

2. Dicerothamnus rhinocerotis Mountain Renosterveld,

3. Passerina truncata Mountain Renosterveld,

4. Pteronia glauca - Euphorbia decussata Escarpment Karoo,

5. Eriocephalus purpureus Hantam Karoo,

6. Pteronia glomerata Roggeveld Karoo,

7. Aridaria noctiflora Tanqua and Loeriesfontein Karoo, and

8. Stipagrostis obtusa Central Tanqua Grassy Plains.

In this paper the associations have also been grouped at a higher hierarchical level into three vegetation groups. The three Mountain Renosterveld vegetation associations are grouped 
together and called Mountain Renosterveld, the Escarpment Karoo, Hantam Karoo and Roggeveld Karoo are collectively termed Winter Rainfall Karoo and the Tanqua and Loeriesfontein Karoo together with the Central Tanqua Grassy Plains are termed Tanqua Karoo.

\section{Materials and methods}

Whittaker's plant diversity plot technique (Shmida 1984) was used to conduct field surveys. The only modification of the methodology described by Shmida (1984) related to the field form and notations used on the field form. A separate column for each size quadrat was provided for on the field form. Additionally, the vegetation of the two $5 \mathrm{~m}^{2}$ quadrats were noted in two separate columns and the $10 \mathrm{~m} \times 10 \mathrm{~m}$ square was separated into two $5 \mathrm{~m} \times 10 \mathrm{~m}$ rectangles and the species were noted apart from one another in two columns on the field form. The columns thus read as follows: ten $1 \mathrm{~m}^{2}$, two $5 \mathrm{~m}^{2}$, two $50 \mathrm{~m}^{2}$ and one $1000 \mathrm{~m}^{2}$ columns. The presence of each species encountered in a quadrat was noted within each column and a percentage cover value given for each species in the $1000 \mathrm{~m}^{2}$ quadrat.

By ensuring that each column contained a list of all species present in that quadrat, more freedom was gained to calculate the number of species present in a quadrat of a different size than actually measured. For example, if the number of species for a $15 \mathrm{~m}^{2}$ quadrat is required, the total number of different species across, for example, the ten $1 \mathrm{~m}^{2}$ and a one $5 \mathrm{~m}^{2}$ quadrat could be tallied.

Forty sample plots were surveyed across the Hantam, Tanqua and Roggeveld regions in the different vegetation associations prevalent in the area (Van der Merwe et al. 2008a, 2008b). Environmental data such as altitude, aspect, slope, position on the slope, geology, topography, percentage stone and stone size, soil type and colour, drainage, erosion, trampling and soil compaction were noted at each site. 
The total species number for seven plot sizes $\left(1 \mathrm{~m}^{2}, 5 \mathrm{~m}^{2}, 10 \mathrm{~m}^{2}, 20 \mathrm{~m}^{2}, 50 \mathrm{~m}^{2}, 100 \mathrm{~m}^{2}\right.$ and $1000 \mathrm{~m}^{2}$ ) were determined by using the mean of the ten $1 \mathrm{~m}^{2}$ plots for the $1 \mathrm{~m}^{2}$ plot, the mean of the two $5 \mathrm{~m}^{2}$ plots for the $5 \mathrm{~m}^{2}$ plot, mean of the total of ten $1 \mathrm{~m}^{2}$ plots and the total of two 5 $\mathrm{m}^{2}$ plots for the $10 \mathrm{~m}^{2}$ plot, total of the ten $1 \mathrm{~m}^{2}$ and the two $5 \mathrm{~m}^{2}$ plots for a $20 \mathrm{~m}^{2}$ plot, mean of the two $50 \mathrm{~m}^{2}$ plots for a $50 \mathrm{~m}^{2}$ plot, the total of the two $50 \mathrm{~m}^{2}$ plots for a $100 \mathrm{~m}^{2}$ plot and the total for the $1000 \mathrm{~m}^{2}$ plot. These seven plot sizes were used to construct Type II speciesarea curves (Scheiner 2003, 2004) for each of the 40 plots sampled using three different functions namely:

1) the untransformed linear function between species richness (S) and area (A): $\mathrm{S}=\mathrm{zA}+\mathrm{c}$ where $\mathrm{c}$ and $\mathrm{z}$ are constants for the slope and $\mathrm{y}$-intercept respectively;

2) the power function, typically expressed as the log transformation: $\log S=\log c+z \log A ;$ and

3) the exponential function, expressed as a semilog function: $S=z \log A+c($ Veech 2000).

A fourth function, the logistic function, was not used in the study since the whole community was not sampled. If sampling covers the whole of a community, the logistic is expected to be the best model to describe the species-area relationship (He \& Legendre 1996).

For each site the equation, $r$-value and $p$-value (significance) were determined using the STATISTICA computer package (StaSoft, Inc. Version 7 and Version 8, 2300 East $14^{\text {th }}$ Street, Tulsa, OK 74104). Upon testing for normality and finding that the distribution was normal, an Analysis of Variance (ANOVA, Bonferroni's post-hoc test) was conducted to compare the slopes of the species-area curves between the associations and three vegetation groups for the exponential function. The statistical significance of the differences between the slope values and intercepts of the exponential curves were analysed by an Analysis of Covariance (Quinn \& Keough 2002) with GraphPad Prism 4.03 for Windows (GraphPad software, San Diego, California, USA, www.graphpad.com).

To illustrate the variation in species-area curves produced using the exponential function and species richness in relation to environmental data a transect of ten survey plots running from 
west to east through the study area was compiled. This transect stretches eastwards from the Tanqua Karoo, across the Roggeveld escarpment onto the Roggeveld plateau.

\section{Results and discussion}

Whittaker (1977) contended that patterns of plant diversity can be elucidated only by systematic surveys and by sampling at multiple spatial scales. Whittaker's plant diversity plot method has proved to be an efficient method of sampling used around the world, especially in semi-arid environments (Shmida 1984, Stohlgren et al. 1995).

Since most biological communities demonstrate natural patchiness and clumping of species, samples drawn from natural communities are not random samples from a multinomial population (Heltshe \& Forrester 1983). Consequently, samples taken are not random samples of individuals but random samples of space (Heltshe \& Forrester 1983), leading to an array of possible species-area curves.

In general, the exponential and power functions provided a better fit to the data than the untransformed linear function (see r-values and p-values in Table 1) except in plots W17 and W18 (Table 1), located in the Tanqua Karoo, where the untransformed linear function produced the best fit. The exponential function performed marginally better than the power function with 23 out of the 40 plots producing the best fit (r-value) with the exponential function. These findings support Tjørve (2003) who stated that the power and exponential models not only dominate the literature but are proven models that perform well, but contrast with the findings of Connor and McCoy (1979) who studied 100 cases and concluded that the power function is usually superior in linearising species-area relationships. Veech (2000) indicates the importance of not choosing just one function and suggests investigating the power, linear and exponential functions, especially given that none of these three functions consistently fits species-area data better than the others. 
Table 1. Vegetation group, plant association number, survey plot number, untransformed linear function, exponential function, power function, $r$-value and $\mathrm{p}$ value and species richness (at $1000 \mathrm{~m}^{2}$ ) for 40 modified Whittaker diversity plots surveyed in the Hantam-Tanqua-Roggeveld subregion in 2005

\begin{tabular}{|c|c|c|c|c|c|c|c|c|c|c|c|c|}
\hline \multirow[t]{2}{*}{ Vegetation group } & \multirow{2}{*}{$\begin{array}{l}\text { Plant } \\
\text { asso- } \\
\text { ciation } \\
\text { no. }\end{array}$} & \multirow{2}{*}{$\begin{array}{l}\text { Survey } \\
\text { plot no. }\end{array}$} & \multicolumn{3}{|c|}{ Untransformed linear function } & \multicolumn{3}{|c|}{ Exponential (Semi-log) function } & \multicolumn{3}{|c|}{ Power (Log-log) function } & \multirow{2}{*}{$\begin{array}{l}\text { Species } \\
\text { richness } \\
\text { at } \\
1000 \mathrm{~m}^{2}\end{array}$} \\
\hline & & & Linear equation & $\begin{array}{l}\mathrm{r}- \\
\text { value }\end{array}$ & $p$-value & Linear equation & \begin{tabular}{|l|}
$r-$ \\
value
\end{tabular} & p-value & Linear equation & $\begin{array}{l}\mathrm{r}- \\
\text { value }\end{array}$ & p-value & \\
\hline Mountain Renosterveld & 1 & W23 & $y=49.1038+0.0521 x$ & 0.7987 & $0.0312^{*}$ & $y=24.0807+24.4289 x$ & 0.9862 & $0.0000^{* * *}$ & $y=1.4529+0.1976 x$ & 0.9567 & $0.0007^{* * *}$ & 99 \\
\hline Mountain Renosterveld & 1 & W24 & $y=29.0398+0.0455 x$ & 0.8813 & $0.0087^{\star *}$ & $y=10.0469+19.2775 x$ & 0.9821 & $0.0000^{* * *}$ & $y=1.1934+0.2327 x$ & 0.9875 & $0.0000^{\star \star *}$ & 72 \\
\hline Mountain Renosterveld & 1 & W25 & $y=21.6580+0.0446 x$ & 0.9130 & $0.0041^{* *}$ & $y=4.6157+17.7535 x$ & 0.9568 & $0.0007^{\star * *}$ & $y=1.0403+0.2599 x$ & 0.9815 & $0.0000^{\star \star *}$ & 65 \\
\hline Mountain Renosterveld & 1 & W26 & $y=39.4736+0.0445 x$ & 0.8016 & $0.0302^{*}$ & $y=18.2448+20.7637 x$ & 0.9846 & $0.0000^{\star \star *}$ & $y=1.3506+0.2042 x$ & 0.9629 & $0.0005^{\star * *}$ & 82 \\
\hline Mountain Renosterveld & 1 & W27 & $y=37.7687+0.0340 x$ & 0.7464 & $0.0539^{\text {ns }}$ & $y=20.0244+16.9636 x$ & 0.9806 & $0.0001^{* * *}$ & $y=1.3542+0.1827 x$ & 0.9513 & $0.0010^{* * *}$ & 70 \\
\hline Mountain Renosterveld & 2 & W3 & $y=18.7349+0.0573 x$ & 0.9535 & $0.0009^{* \star *}$ & $y=-0.8280+21.1255 x$ & 0.9256 & $0.0028^{\star \star}$ & $y=0.9086+0.3221 x$ & 0.9745 & $0.0002^{* \star \star}$ & 75 \\
\hline Mountain Renosterveld & 2 & W4 & $y=24.3334+0.0496 x$ & 0.8578 & $0.0135^{*}$ & $y=2.7603+21.6392 x$ & 0.9847 & $0.0000^{\star \star *}$ & $y=0.9742+0.3247 x$ & 0.9669 & $0.0004^{\star \star *}$ & 72 \\
\hline Mountain Renosterveld & 2 & W11 & $y=19.3549+0.0445 x$ & 0.8589 & $0.0133^{*}$ & $y=0.0385+19.3867 x$ & 0.9844 & $0.0000^{* * *}$ & $y=0.8293+0.3556 x$ & 0.9752 & $0.0002^{* * *}$ & 62 \\
\hline Mountain Renosterveld & 2 & W12 & $y=32.0579+0.0347 x$ & 0.7739 & $0.0412^{\star}$ & $y=14.4695+16.9413 x$ & 0.9937 & $0.0000^{\star \star *}$ & $y=1.2444+0.2121 x$ & 0.9605 & $0.0006^{* * *}$ & 65 \\
\hline Mountain Renosterveld & 2 & W20 & $y=31.6149+0.0492 x$ & 0.8376 & $0.0187^{\star}$ & $y=9.5255+21.9633 x$ & 0.9837 & $0.0000^{* * *}$ & $y=1.1713+0.2650 x$ & 0.9568 & $0.0007^{* * *}$ & 79 \\
\hline Mountain Renosterveld & 2 & W21 & $Y=31.1870+0.0557 x$ & 0.8083 & $0.0278^{*}$ & $y=4.6272+25.9831 x$ & 0.9922 & $0.0000^{* * *}$ & $y=1.0822+0.3176 x$ & 0.9692 & $0.0003^{* * *}$ & 84 \\
\hline Mountain Renosterveld & 2 & W28 & $y=45.5203+0.0533 x$ & 0.7720 & $0.0420^{* *}$ & $y=18.4944+26.0171 x$ & 0.9930 & $0.0000^{* * *}$ & $y=1.3691+0.2307 x$ & 0.9568 & $0.0007^{* * *}$ & 96 \\
\hline Mountain Renosterveld & 2 & W29 & $y=36.0150+0.0509 x$ & 0.8585 & $0.0134^{*}$ & $y=13.8923+22.1935 x$ & 0.9851 & $0.0000^{\star \star *}$ & $y=1.2967+0.2221 x$ & 0.9831 & $0.0000^{* * *}$ & 85 \\
\hline Mountain Renosterveld & 2 & W30 & $y=41.5343+0.0536 x$ & 0.8358 & $0.0192^{*}$ & $y=17.3209+24.0287 x$ & 0.9867 & $0.0000^{\star \star *}$ & $y=1.3596+0.2174 x$ & 0.9719 & $0.0003^{* \star *}$ & 93 \\
\hline
\end{tabular}




\begin{tabular}{|c|c|c|c|c|c|c|c|c|c|c|c|c|}
\hline Mountain Renosterveld & 2 & W40 & $y=24.2869+0.0433 x$ & 0.8504 & $0.0153^{*}$ & $y=5.3234+18.9851 x$ & 0.9810 & $0.0001^{* * *}$ & $y=1.0237+0.2898 x$ & 0.9608 & $0.0006^{\star * *}$ & 66 \\
\hline Mountain Renosterveld & 3 & W7 & $y=15.1610+0.0653 x$ & 0.9551 & $0.0008^{* * *}$ & $y=-7.1957+24.1232 x$ & 0.9286 & $0.0025^{\star *}$ & $y=0.7054+0.4058 x$ & 0.9975 & $0.0000^{* * *}$ & 79 \\
\hline Mountain Renosterveld & 3 & W8 & $y=19.6701+0.0807 x$ & 0.9639 & $0.0005^{* * *}$ & $y=-7.0353+29.1419 x$ & 0.9165 & $0.0037^{* *}$ & $y=0.8691+0.3751 x$ & 0.9895 & $0.0000^{* * *}$ & 99 \\
\hline Winter Rainfall Karoo & 4 & W5 & $y=36.8267+0.0556 x$ & 0.8177 & $0.0246^{*}$ & $y=10.6242+25.7069 x$ & 0.9959 & $0.0000^{\star * *}$ & $y=1.2064+0.2814 x$ & 0.9454 & $0.0013^{\star *}$ & 90 \\
\hline Winter Rainfall Karoo & 4 & W6 & $y=27.0250+0.0751 x$ & 0.9210 & $0.0032^{* *}$ & $y=-1.2689+29.6096 x$ & 0.9555 & $0.0008^{\star \star *}$ & $y=1.0432+0.3289 x$ & 0.9869 & $0.0000^{\star \star *}$ & 100 \\
\hline Winter Rainfall Karoo & 4 & W38 & $y=22.5390+0.0495 x$ & 0.8600 & $0.0130^{*}$ & $y=1.4013+21.3106 x$ & 0.9745 & $0.0002^{\star \star *}$ & $y=0.9461+0.3244 x$ & 0.9727 & $0.0002^{\star \star *}$ & 70 \\
\hline Winter Rainfall Karoo & 4 & W39 & $y=21.8865+0.0482 x$ & 0.8367 & $0.0189^{*}$ & $y=0.3194+21.4625 x$ & 0.9804 & $0.0001^{* \star *}$ & $y=0.8525+0.3680 x$ & 0.9562 & $0.0008^{* \star *}$ & 68 \\
\hline Winter Rainfall Karoo & 5 & W9 & $y=23.7785+0.0407 x$ & 0.8637 & $0.0122^{*}$ & $y=6.3768+17.5341 x$ & 0.9800 & $0.0001^{\star \star *}$ & $y=1.0580+0.2639 x$ & 0.9750 & $0.0002^{\star * \star}$ & 63 \\
\hline Winter Rainfall Karoo & 5 & W10 & $y=27.5470+0.0484 x$ & 0.8502 & $0.0154^{*}$ & $y=6.1057+21.3899 x$ & 0.9898 & $0.0000^{* \star *}$ & $y=1.0776+0.2902 x$ & 0.9657 & $0.0004^{* * *}$ & 74 \\
\hline Winter Rainfall Karoo & 5 & W31 & $y=25.3184+0.0328 x$ & 0.8813 & $0.0087^{\star *}$ & $y=11.7322+13.8133 x$ & 0.9779 & $0.0001^{* \star *}$ & $y=1.1873+0.1928 x$ & 0.9882 & $0.0000^{\star \star \star}$ & 57 \\
\hline Winter Rainfall Karoo & 5 & W32 & $y=30.1233+0.0182 x$ & 0.6154 & $0.1413^{\text {ns }}$ & $y=18.3652+10.7066 x$ & 0.9552 & $0.0008^{\star * *}$ & $y=1.2718+0.1614 x$ & 0.9030 & $0.0053^{\star \star}$ & 47 \\
\hline Winter Rainfall Karoo & 5 & W33 & $y=25.0023+0.0375 x$ & 0.8241 & $0.0226^{*}$ & $y=7.7520+17.0365 x$ & 0.9855 & $0.0000^{* * *}$ & $y=1.0659+0.2653 x$ & 0.9526 & $0.0009^{* * *}$ & 61 \\
\hline Winter Rainfall Karoo & 5 & W34 & $y=24.6008+0.0386 x$ & 0.8445 & $0.0168^{*}$ & $y=7.9234+16.7581 x$ & 0.9649 & $0.0004^{* * *}$ & $y=1.0759+0.2569 x$ & 0.9450 & $0.0013^{\star *}$ & 62 \\
\hline Winter Rainfall Karoo & 5 & W35 & $y=13.9400+0.0218 x$ & 0.9113 & $0.0043^{* *}$ & $y=5.5902+8.6884 x$ & 0.9575 & $0.0007^{* * *}$ & $y=0.9287+0.2001 x$ & 0.9875 & $0.0000^{* * *}$ & 35 \\
\hline Winter Rainfall Karoo & 5 & W36 & $y=28.9600+0.0443 x$ & 0.7715 & $0.0422^{*}$ & $y=6.6151+21.5481 x$ & 0.9872 & $0.0000^{* * *}$ & $y=1.0447+0.3123 x$ & 0.9364 & $0.0019^{* *}$ & 71 \\
\hline Winter Rainfall Karoo & 5 & W37 & $y=27.7537+0.0540 x$ & 0.8268 & $0.0218^{*}$ & $y=3.7763+23.9062 x$ & 0.9640 & $0.0005^{\star \star *}$ & $y=1.0826+0.2910 x$ & 0.9678 & $0.0004^{* * *}$ & 79 \\
\hline Winter Rainfall Karoo & 6 & W1 & $y=13.5255+0.0472 x$ & 0.9522 & $0.0009^{* \star *}$ & $y=-2.3938+17.2654 x$ & 0.9164 & $0.0037^{* *}$ & $y=0.7286+0.3506 x$ & 0.9706 & $0.0003^{* * *}$ & 60 \\
\hline Winter Rainfall Karoo & 6 & W2 & $y=23.5017+0.0438 x$ & 0.9016 & $0.0055^{\star \star}$ & $y=6.2029+17.8348 x$ & 0.9677 & $0.0004^{* * *}$ & $y=1.0776+0.2543 x$ & 0.9823 & $0.0000^{* * *}$ & 66 \\
\hline Winter Rainfall Karoo & 6 & W22 & $y=16.3957+0.0156 x$ & 0.6563 & $0.1093^{\text {ns }}$ & $y=6.9467+8.7301 x$ & 0.9656 & $0.0004^{* * *}$ & $y=0.8811+0.2469 x$ & 0.9029 & $0.0054^{\star *}$ & 31 \\
\hline Tanqua Karoo & 7 & W13 & $y=4.7679+0.0256 x$ & 0.9779 & $0.0001^{* \star *}$ & $y=-3.1667+8.8532 x$ & 0.8914 & $0.0070^{\star *}$ & $y=0.2360+0.4044 x$ & 0.9888 & $0.0000^{\star \star \star}$ & 30 \\
\hline Tanqua Karoo & 7 & W14 & $y=11.3370+0.0155 x$ & 0.7842 & $0.0368^{*}$ & $y=3.6387+7.4471 x$ & 0.9943 & $0.0000^{\star \star *}$ & $y=0.7216+0.2617 x$ & 0.9589 & $0.0006^{\star * *}$ & 26 \\
\hline
\end{tabular}




\begin{tabular}{|c|c|c|c|c|c|c|c|c|c|c|c|c|}
\hline Tanqua Karoo & 7 & W17 & $y=1.8790+0.0112 x$ & 0.9818 & $0.0000^{* * *}$ & $y=-1.3900+3.7252 x$ & 0.8621 & $0.0126^{*}$ & $y=-0.2211+0.4402 x$ & 0.9480 & $0.0012^{* *}$ & 13 \\
\hline Tanqua Karoo & 7 & W19 & $y=9.0794+0.0174 x$ & 0.9067 & $0.0049^{* *}$ & $y=2.2380+7.0661 x$ & 0.9690 & $0.0003^{* *}$ & $y=0.6615+0.2578 x$ & 0.9879 & $0.0000^{* * *}$ & 26 \\
\hline Tanqua Karoo & 8 & W15 & $y=4.4008+0.0100 x$ & 0.8660 & $0.0117^{*}$ & $y=0.1601+4.2870 x$ & 0.9746 & $0.0002^{\star \star *}$ & $y=0.2469+0.3211 x$ & 0.9859 & $0.0000^{\star \star *}$ & 14 \\
\hline Tanqua Karoo & 8 & W16 & $y=3.8269+0.0084 x$ & 0.9364 & $0.0019^{\star *}$ & $y=0.8376+3.1794 x$ & 0.9380 & $0.0018^{\star *}$ & $y=0.3121+0.2488 x$ & 0.9764 & $0.0002^{* * *}$ & 12 \\
\hline Tanqua Karoo & 8 & W18 & $y=0.7566+0.0082 x$ & 0.9955 & $0.0000^{* * *}$ & $y=-1.0362+2.2944 x$ & 0.7350 & $0.0598^{\text {ns }}$ & $y=-0.2429+0.2737 x$ & 0.7350 & $0.0598^{\text {ns }}$ & 9 \\
\hline
\end{tabular}

ns Not significant, ${ }^{*} p<0.05$ Significant, ${ }^{* *} p<0.01$ Highly significant, ${ }^{* * *} p<0.001$ Very highly significant 
As a consequence of the assumed linearity of the models the rate at which species accumulate with increments in area (the slope of the line) is a constant value and this can be used to make comparisons between different areas. The slope of the exponential function obtained for the 40 plots surveyed, varied widely from 2.2944 for plot W18 in the Tanqua Karoo to 29.6096 on the Roggeveld escarpment for plot W6 (Table 1). Slopes for the Tanqua Karoo vegetation ranged from 2.2944 (plot W18) to 8.8532 (plot W13), whereas for the Winter Rainfall Karoo the range was from 8.6884 (plot W35) to 29.6096 (plot W6) and in the Mountain Renosterveld vegetation, slopes varying from 16.9413 (plot W12) to 29.1419 (plot W8) were found. The range of slopes was the largest for the Winter Rainfall Karoo, which is the most diverse vegetation group, and smallest for the Tanqua Karoo vegetation. Both the untransformed linear function and power function demonstrated the same trends as the exponential function with the Tanqua Karoo having the lowest slope values, the winter Rainfall Karoo showing a large range of slope values and the Mountain Renosterveld having a smaller range, but values generally being quite high. A large range of slopes within a vegetation unit was also reported by Palmer and White (1994) who state that there is no such thing as the species-area curve for a given location. Rather, there is a suite of species-area curves, each with its own characteristics (Palmer \& White 1994).

Since the exponential function produced marginally better results than the other functions these results were further analysed. The ANOVA on the exponential curves revealed that the slopes obtained for the Tanqua Karoo were significantly shallower than those obtained for the Winter Rainfall Karoo $(p<0.0001)$ and Mountain Renosterveld $(p<0.0001)$ (Table 2). No significant difference was found between the slopes of the Mountain Renosterveld and Winter Rainfall Karoo $(p=0.099)$. Within the Mountain Renosterveld group, no significant difference was found between associations 1 and 2, these associations were also related to association 3 of the Mountain Renosterveld group which in turn was not significantly different from the association 4 (Escarpment Karoo) of the Winter Rainfall Karoo (Table 2). The other two associations within the Winter Rainfall Karoo were not significantly different yet, the transitional Roggeveld Karoo (association 6) was also similar to association 7 of the Tanqua 
Table 2. Mean slope values for the eight associations and three broad vegetation groups in the Hantam-Tanqua-Roggeveld subregion

\begin{tabular}{|c|c|c|c|}
\hline \multirow{2}{*}{$\begin{array}{l}\text { Association } \\
1 . \quad \text { Rosenia oppositifolia } \\
\text { Mountain Renosterveld }\end{array}$} & \multirow{2}{*}{$\begin{array}{l}\text { Vegetation group } \\
\text { Mountain Renosterveld }\end{array}$} & \multicolumn{2}{|c|}{ Mean slope value } \\
\hline & & $19.837^{\text {cd }}$ & \\
\hline $\begin{array}{l}\text { 2. Dicerothamnus rhinocerotis } \\
\text { Mountain Renosterveld }\end{array}$ & Mountain Renosterveld & $21.826^{\mathrm{cd}}$ & \\
\hline \multirow[t]{2}{*}{$\begin{array}{l}\text { 3. Passerina truncata Mountain } \\
\text { Renosterveld }\end{array}$} & Mountain Renosterveld & $26.633^{d}$ & \\
\hline & Mountain Renosterveld & & $21.807^{\mathrm{a}}$ \\
\hline $\begin{array}{l}\text { 4. Pteronia glauca - Euphorbia } \\
\text { decussata Escarpment Karoo }\end{array}$ & Winter Rainfall Karoo & $24.522^{\mathrm{d}}$ & \\
\hline $\begin{array}{l}\text { 5. Eriocephalus purpureus } \\
\text { Hantam Karoo }\end{array}$ & Winter Rainfall Karoo & $16.820^{\mathrm{C}}$ & \\
\hline \multirow[t]{2}{*}{$\begin{array}{l}\text { 6. Pteronia glomerata } \\
\text { Roggeveld Karoo }\end{array}$} & Winter Rainfall Karoo & $14.610^{\mathrm{bc}}$ & \\
\hline & Winter Rainfall Karoo & & $18.331^{\mathrm{a}}$ \\
\hline $\begin{array}{l}\text { 7. Aridaria noctiflora Tanqua } \\
\text { and Loeriesfontein Karoo }\end{array}$ & Tanqua Karoo & $6.773^{\mathrm{ab}}$ & \\
\hline \multirow[t]{3}{*}{$\begin{array}{l}\text { 8. Stipagrostis obtusa Central } \\
\text { Tanqua Grassy Plains }\end{array}$} & Tanqua Karoo & $3.254^{\mathrm{a}}$ & \\
\hline & Tanqua Karoo & & $5.265^{b}$ \\
\hline & $p$-value & $P<0.05$ & $P<0.0001$ \\
\hline
\end{tabular}


Karoo (Table 2). Associations 7 and 8 of the Tanqua Karoo did not differ significantly (Table 2).

The large difference between species-area curves within the study area can be ascribed to factors such as differences in patch or habitat size and structural differences in community organisation resulting from different species abundance distributions (see Scheiner et al. 2000, He \& Legendre 2002, Scheiner \& Jones 2002, Keeley 2003, Scheiner 2003). These may be tied to patterns of life form distributions, which result from different environmental conditions (Keeley 2003). The Tanqua Karoo is a more arid environment with a mean annual precipitation varying from $<100 \mathrm{~mm}$ to $200 \mathrm{~mm}$ (Schulze 1997) while rainfall in the Winter Rainfall Karoo and Mountain Renosterveld ranges from $100 \mathrm{~mm}$ to $400 \mathrm{~mm}$ in normal years and to more than $400 \mathrm{~mm}$ in above-normal years (Schulze 1997). In general, the habitat is more homogeneous at the Whittaker plot size in the Tanqua Karoo than in the other vegetation groups, resulting in shallower slopes and lower intercepts in this vegetation group.

A west to east transect of ten survey plots through the Tanqua Karoo, up the Roggeveld Escarpment, across the Roggeveld Mountains and Roggeveld plateau towards the strongly summer rainfall Nama Karoo Biome (Rutherford \& Westfall 1994) is presented to illustrate the most prominent changes in the vegetation and how these are reflected in the species-area curves. A profile of this transect illustrates the altitudinal variation, species richness at the $1000 \mathrm{~m}^{2}$ scale and the sequence of vegetation associations (Figure 2). Differences in the slopes and intercepts of the species-area curves among the various sites are discussed only for the exponential function due to its slightly better fit to the data.

Species richness provides an instantly comprehensible expression of diversity (Magurran 1988), and clearly illustrates the changes along the altitudinal gradient. The lowest species counts (1000 $\mathrm{m}^{2}$ plots) were found in the low-lying Tanqua Karoo, the intermediate counts on the high-lying inland plateau and the highest counts on the steep escarpment (Figure 2). Altitude is an important contributor to explaining species diversity (Körner 2000) and altitudinal gradients have been recognised as an important buffer in the event of climate 


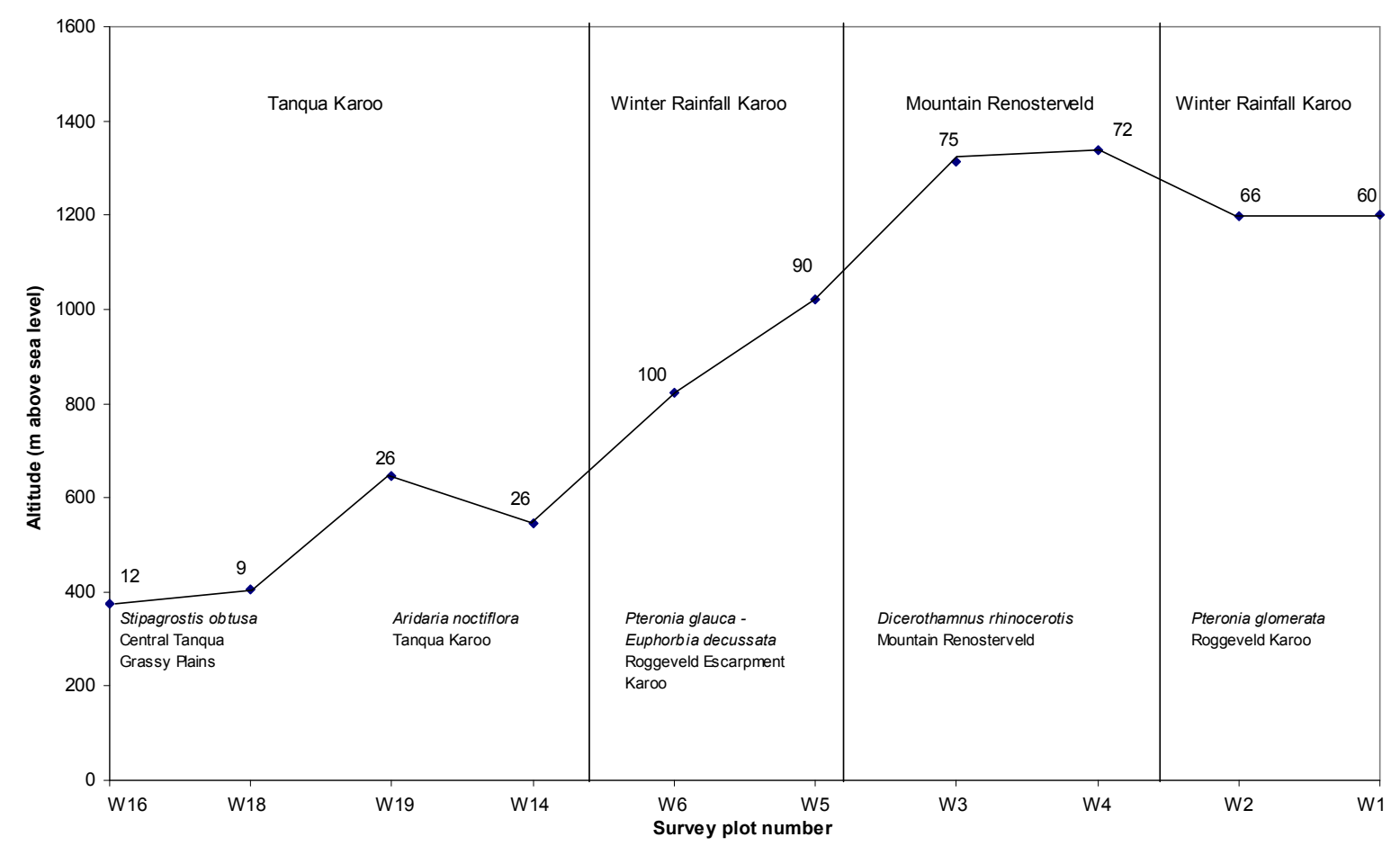

Fig. 2 Profile from west to east along a transect through three vegetation groups and five associations in the Hantam-Tanqua-Roggeveld subregion. Values for species richness are indicated for each survey plot

change (Bond \& Richardson 1990). Because mountain habitats could provide refugia for species during climate change (Midgley et al. 2000) it emphasizes the importance of conserving mountain communities (Burke et al. 2003).

The transect begins in the west with two sites located in the Tanqua Karoo, survey plots W16 and W18, falling within the Stipagrostis obtusa Central Tanqua Grassy Plains association (Van der Merwe et al. 2008b). Species richness of survey plot W16 at an altitude of $374 \mathrm{~m}$ above sea level (Figure 2), with a low vegetation cover of $40 \%$ but a high rock cover of $99 \%$, was found to be 12 species per $1000 \mathrm{~m}^{2}$ (Table 1). Survey plot W18 had a low species richness of only 9 species per $1000 \mathrm{~m}^{2}$ (Table 1) and was surveyed at an altitude of $405 \mathrm{~m}$ above sea level (Figure 2), on level terrain with a very low vegetation cover of approximately $10 \%$ but a high rock cover of $99 \%$. These two plots are characterised by the lowest species richness along the transect (and also in the entire study area) and species-area curves with the shallowest slopes (Figure 3c). The first plot (W16) was located in a relatively homogeneous succulent patch and was dominated by three succulent species with only a few individuals of the other nine species present. In the case of plot W18, only one species, the 




b)

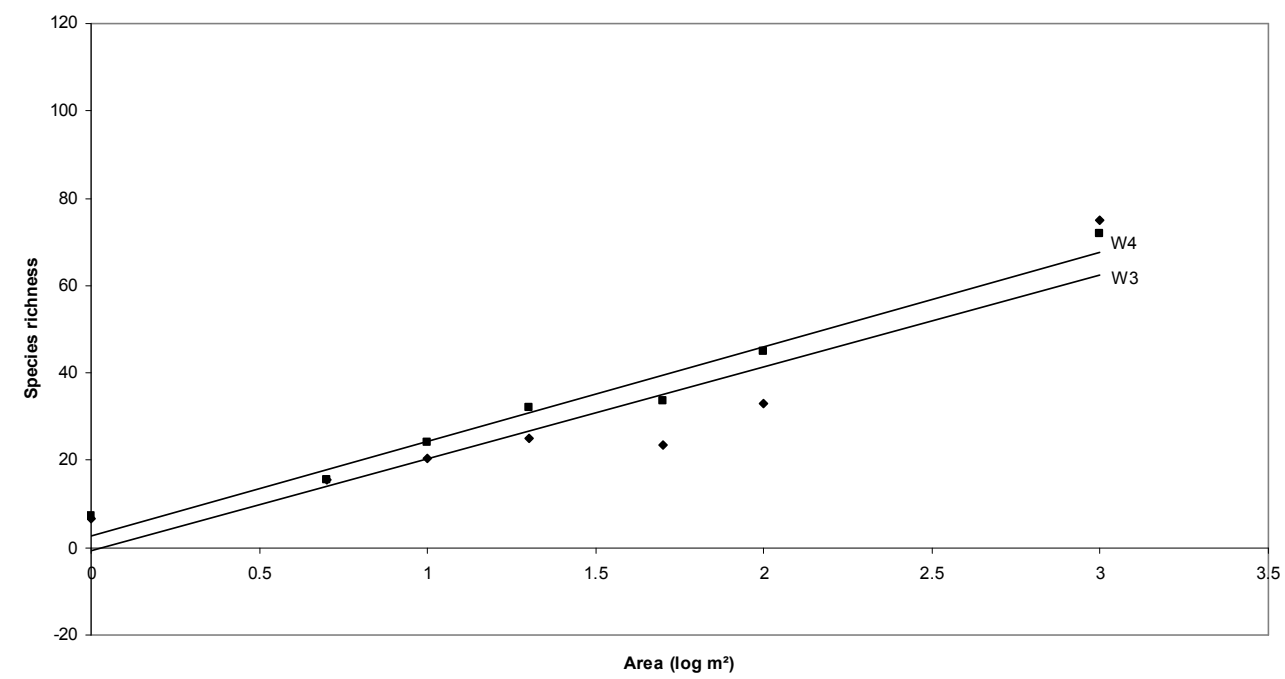

c)

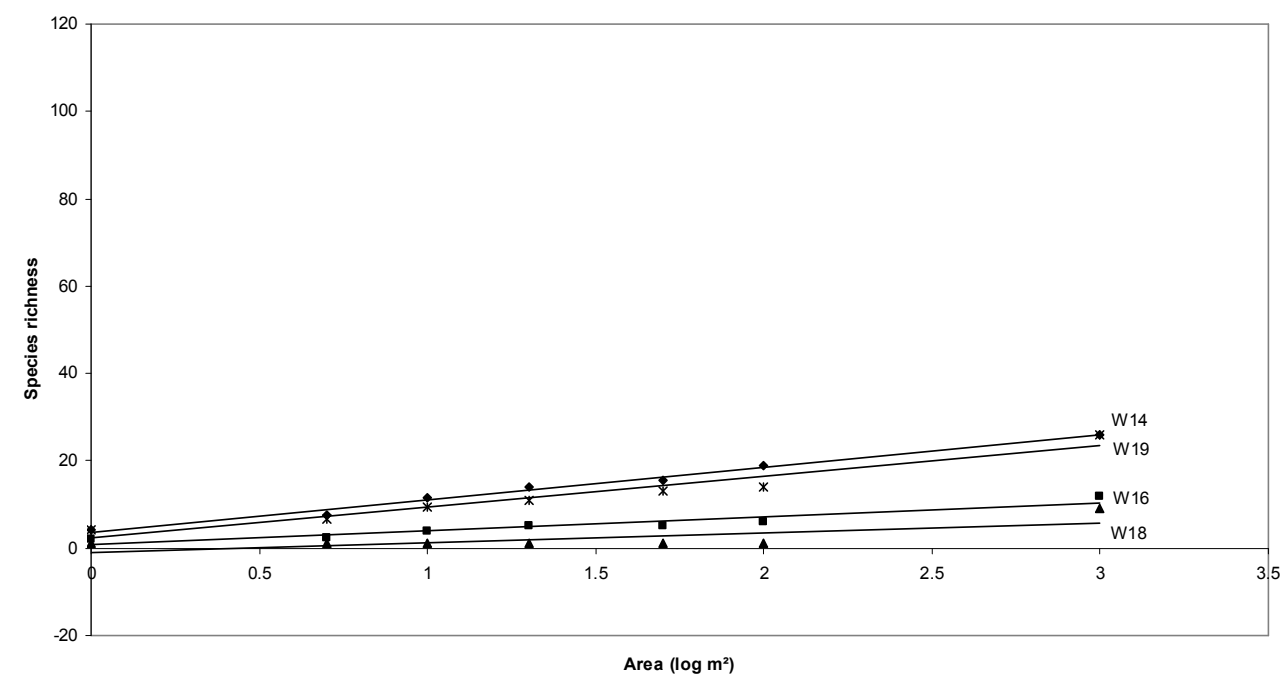


Fig. 3 Species-area curves for 10 plots along a transect from west to east through the study area comparing the exponential functions for the three vegetation groups: (a) Winter Rainfall Karoo; (b) Mountain Renosterveld; and (c) Tanqua Karoo

grass Stipagrostis obtusa, dominated with the other eight species represented by only one individual or a cover of $<1 \%$. The dominance of a few species and small species richness values resulted in the very shallow species-area curve slopes. There was no sudden increase in species numbers at a certain plot size, indicating a large patch size and homogeneous vegetation. Slope values of the exponential function did not differ significantly $(p=0.4320)$ between the two sites although the intercept did differ significantly $(p=0.0078)$, (Figure $3 c)$.

The next two plots along the transect were also surveyed in the Tanqua Karoo but in the Aridaria noctiflora Tanqua Karoo association (Van der Merwe et al. 2008b). Survey plot W19 and W14 were surveyed at a higher altitude (Figure 2) and vegetation cover (50-75\%), but lower rock cover $(70-95 \%)$ than the previous two plots. Although the species richness at these two sites was higher (26 species per $1000 \mathrm{~m}^{2}$, Table 1) than at the previous two sites and the slopes of the species-area curves steeper (Figure 3c), these values still represent the lower end of the scale for the study area. In both of these plots the greatest contribution to the vegetation cover was made by five species while, the other 21 species did not contribute notably. The species-area curves remained shallow due to the very gradual increase in number of species encountered as the plots were surveyed and remained shallow to the 1000 $\mathrm{m}^{2}$ where species richness remained small. No sudden increase in species numbers at any plot size was found within the plot indicating that the vegetation surveyed was homogeneous. The exponential function slopes of the two plots did not differ significantly $(p=0.6747)$ but the intercepts did differ significantly $(p=0.0277)$. A comparison between the two associations in the Tanqua Karoo revealed that the slopes of the exponential species-area curve function differed significantly between the associations $(p=0.0001)$, (Figure 3c).

Further eastwards the next two plots were located on the Roggeveld Escarpment in the Pteronia glauca - Euphorbia decussata Roggeveld Escarpment Karoo association (Van der Merwe et al. 2008b). Plot W6 and W5 were surveyed at intermediate altitudes (Figure 2), the vegetation cover on both sites was $75 \%$ and rock cover ranged from 80 to $95 \%$. The species 
richness of the plots was 100 species per $1000 \mathrm{~m}^{2}$ and 90 species per $1000 \mathrm{~m}^{2}$ (Table 1) respectively. The high species richness can possibly be ascribed to the vegetation being transitional from the Tanqua Karoo (Succulent Karoo Biome) to the Mountain Renosterveld (Fynbos Biome). Transition zones are hypothesised to have a greater species richness than adjacent areas (Shmida \& Wilson 1985, Scheiner \& Rey-Benayas 1994). The slopes of the species-area curves of these two plots were the steepest of all plots along the transect (Figure 3a). In plot W6 one species was more abundant and in plot W5 two species dominated, however, the bulk of the species in these two plots were common occurring frequently throughout the plot. Various geophyte and annual species with low abundances were continuously added as the plot size was enlarged. It was clear that an asymptote in species richness had not yet been reached at the $1000 \mathrm{~m}^{2}$ scale. The slopes of the exponential function species-area curves of the two sites sampled did not differ significantly ( $p$ $=0.3770)$ neither did the intercepts $(p=0.1125)$.

From the Roggeveld Escarpment the transect runs through the Mountain Renosterveld of the Dicerothamnus rhinocerotis Mountain Renosterveld association (Van der Merwe et al. 2008a). Plot W3 and W4 were the two highest altitude plots surveyed (Figure 2). Both plots had a $60 \%$ vegetation cover and a $75 \%$ rock cover and species richness of 75 and 72 species per $1000 \mathrm{~m}^{2}$ respectively (Table 1). The species-area curves produced much steeper slopes (Figure 3b) than those produced for the Tanqua Karoo. These plots were relatively homogeneous and dominated by either Dicerothamnus rhinocerotis or Merxmuellera stricta. The bulk of the species were common throughout all the smaller plots surveyed, but many geophyte species with a low abundance were encountered. Species richness had not yet reached an asymptote at the $1000 \mathrm{~m}^{2}$ scale. Species-area curve slopes for the exponential function of the two sampled sites were not significantly different $(p=0.9057)$, neither were the intercepts $(p=0.2595)$. The exponential function slopes of these two Mountain Renosterveld plots did not differ significantly from the Roggeveld Escarpment plots $(p=0.1870)$ or Roggeveld Karoo plots $(p=0.6256)$. 
The last two plots (W2 and W1) were surveyed in the Winter Rainfall Karoo on the eastern fringes of the study area in the Pteronia glomerata Roggeveld Karoo association (Van der Merwe et al. 2008b) at a slightly lower altitude than the preceding two plots (Figure 2). Vegetation cover varied between 50 and $60 \%$ and rock cover was low $(<1-10 \%)$. Species richness ranged from 60 to 66 species per $1000 \mathrm{~m}^{2}$ (Table 1). These relatively homogeneous plots were dominated by one (plot W2) or two (plot W1) species and produced species-area slopes less steep (Figure 3a) than those for plots W3 and W4 of the Mountain Renosterveld vegetation group. The bulk of the species were common and found throughout the various plot sizes within the $1000 \mathrm{~m}^{2}$ plot. A large number of different annual and geophyte species contributed to the species richness. Once again, species richness had not yet reached an asymptote within the Whittaker plot dimensions. The exponential function slopes of the species-area curves of the two sampled sites did not differ significantly $(p=0.8886)$, but the intercepts did differ significantly $(p=0.0183)$.

The year 2005, in which the data were collected, was a very poor rainfall year. This is expected to have had a significant effect on the number of species encountered, especially with respect to annuals and geophytes which are responsible for a large part of the species diversity in the region. Aronson and Shmida (1992) confirm this stating that, a general distinction can be drawn between 'good', 'bad' and 'medium' rainfall years and this distinction is immediately reflected in changes in species diversity that are largely dependent on annual, and in the case of the Hantam-Tanqua-Roggeveld subregion also geophytic, species.

At present, biodiversity data for the Succulent Karoo are limited to species richness and a literature search revealed no information pertaining to species-area curves in the region. Correspondence with various other scientists in the region, however, indicated that more data should become available in the near future. Species-area curves are most useful in comparing diversities between geographical regions, habitats, or taxa over a range of sample sizes (Connor \& McCoy 1979) as done in this study. The information gained from the study can be used to guide conservation authorities on which areas to target for conservation. Ironically, the largest formal conservation area in the subregion, the Tankwa Karoo National 
Park, for the most part covers the Tanqua Karoo, which the current study showed to be the area with the lowest diversity. However, the park is expanding along the steep escarpment into the Roggeveld Mountains. These areas were found to be of high diversity value and should be a conservation priority.

Although the logistic model is often applied to calculate the total species richness for a community (He \& Legendre 1996, Scheiner 2003) this practice has not been applied in this study. Caution is necessary when extrapolating from these curves to estimate the number of species in a large region (Connor \& McCoy 1979, Palmer 1990, Palmer \& White 1994, Procheş et al. 2003, Wilson \& Shmida 1984). The failure of the species-area curve methods to predict total species richness could be due to species-area curves being functionally and fundamentally different at different scales (Williams 1964, Palmer 1990). Also, when considering that communities are patchy and samples of fixed size are drawn from a homogeneous population, when, in fact, populations are heterogeneous in time and space (Heltshe \& Forrester 1983), the indiscriminate use of the species-area curve in conservation biology is not advocated.

\section{Conclusions}

Forty Whittaker plots were sampled throughout the Hantam, Tanqua and Roggeveld areas. Analyses of these data revealed an array of species-area curves for each of the functions used (untransformed linear, exponential and power functions), each with its own characteristics. The significance levels of the three functions varied greatly, however, the exponential and power functions produced better r-values and $p$-values.

Each association produced its own species-area curve characteristics as well as species richness values. Slope values for the samples within an association did not differ significantly, although the intercept value often did. Comparisons between associations along a west to east transect through the study area revealed significant differences in the slope value 
between the associations, except for the Dicerothamnus rhinocerotis Mountain Renosterveld which did not differ significantly from the associations bordering it on either side.

Generally, across the ten plots along the transect, the Tanqua Karoo had a low vegetation cover and both a low species richness and species-area curves with shallow slopes. The Roggeveld Escarpment Karoo vegetation, of the Winter Rainfall Karoo vegetation group, which is transitional between the Tanqua Karoo and the Mountain Renosterveld of the Roggeveld Mountains produced the highest species richness and steepest slopes for the species-area curves.

\section{Acknowledgements}

The authors would like to thank the Critical Ecosystem Partnership Fund (CEPF) through the Succulent Karoo Ecosystem Plan/Program (SKEP) initiative for funding the project. The Critical Ecosystem Partnership Fund is a joint initiative of Conservation International, the Global Environmental Facility, the Government of Japan, the MacArthur Foundation and the World Bank. A fundamental goal is to ensure civil society is engaged in biodiversity conservation. The various people who assisted with the field work are gratefully acknowledged. CapeNature, the Department of Tourism, Environment and Conservation (Northern Cape) and SANParks are thanked for the necessary permits and permission to conduct this research. This research was supported by the National Research Foundation under grant number 61277 .

\section{References}

Aronson J, Shmida A (1992) Plant species diversity along a Mediterranean-desert gradient and its correlation with interannual rainfall fluctuations. J Arid Environ 23: 235-247

Bond WJ, Richardson DM (1990) What can we learn from extinctions and invasions about the effects of climate change? S Afr J Sci 86: 429-433 
Burke A, Esler KJ, Pienaar E, Barnard P (2003) Species richness and floristic relationships between mesas and their surroundings in southern African Nama Karoo. Divers Distrib 9: 43-53

Cilliers C, Theron H, Rösch H, Le Roux A (2002) Succulent Karoo Ecosystem Plan, Subregional report, Hantam/Tanqua/Roggeveld. Succulent Karoo Ecosystem Plan report

Connor EF, McCoy ED (1979) The statistics and biology of the species-area relationship. Am Nat 113: $791-833$

Cowling RM, Gibbs Russel GE, Hoffman MT, Hilton-Taylor C (1989) Patterns of plant species diversity in southern Africa. In: Huntley BJ (Ed.). Biotic diversity in southern Africa. Concepts and Conservation, pp. 19-50. Oxford University Press, Cape Town

Cowling RM, Hilton-Taylor C (1994) Patterns of plant diversity and endemism in southern Africa: an overview. In: Huntley BJ (Ed.). Botanical diversity in southern Africa. Strelitzia 1, pp. 31-52. National Botanical Institute, Pretoria

Critical Ecosystem Partnership Fund (2003) Ecosystem Profile: The Succulent Karoo hotspot, Namibia and South Africa. Critical Ecosystem Partnership Fund report

Francis ML, Fey MV, Prinsloo HP, Ellis F, Mills AJ, Medinski TV (2007) Soils of Namaqualand: Compensations for aridity. J Arid Environ 70: 588-603

He F, Legendre P (1996) On species-area relations. Am Nat 4: 719-737

He F, Legendre P (2002) Species diversity patterns derived from species-area models. Ecology 83: 1185-1198

Hellmann JJ, Fowler GW (1999) Bias, precision, and accuracy of four measures of species richness. Ecol Appl 9: 824-834

Heltshe JF, Forrester NE (1983) Estimating species richness using the Jackknife Procedure. Biometrics 39: 1-11

Hilton-Taylor C (1994) Western Cape Domain (Succulent Karoo). In: Davis SD, Heywood VH, Hamilton AC (Eds). Centres of plant diversity. A guide and strategy for their conservation, pp. 201-203. IUCN Publications Unit, Cambridge

Keeley JE (2003) Relating species abundance distributions to species-area curves in two Mediterranean-type shrublands. Divers Distrib 9: 253-259 
Körner C (2000) Why are there global gradients in species richness? Mountains might hold the answer. Trends Ecol Evol 15: 513-514

Magurran AE (1988) Ecological Diversity and its measurement. Cambridge University Press, Cambridge

Midgley GF, Hannah L, Roberts R, MacDonald DJ, Allsopp J (2000) Have pleistocene climatic cycles influenced species richness patterns in the greater Cape Mediterranean Region? J Mediterr Stud 2: 137-144

Mucina L, Jürgens N, Le Roux A, Rutherford MC, Schmiedel U, Esler KJ, Powrie LW, Desmet PG, Milton SJ (2006) Succulent Karoo Biome. In: Mucina L, Rutherford MC (Eds) The vegetation of South Africa, Lesotho and Swaziland. Strelitzia 19, pp. 220-299. South African National Biodiversity Institute, Pretoria

Palmer MW (1990) The estimation of species richness by extrapolation. Ecology 71: 11951198

Palmer MW, White PS (1994) Scale dependence and the species-area relationship. Am Nat 144: $717-740$

Pimm SL, Russel GJ, Gittleman JL, Brooks TM (1995) The future of biodiversity. Science 269: $347-350$

Procheş Ş, Cowling RM, Mucina L (2003) Species-area curves based on relevé data for the Cape Floristic Region. S Afr J of Sci 99: 474-476

Quinn GP, Keough MJ (2002) Experimental design and data analysis for biologists. Cambridge University Press, Cambridge

Rutherford MC, Westfall RH (1994) Biomes of Southern Africa. An objective characterisation. Memoirs of the Botanical Survey of South Africa 63: 1-94

Scheiner SM (2003) Six types of species-area curves. Global Ecol Biogeogr 12: 441-447

Scheiner SM (2004) A mélange of curves - further dialogue about species-area relationships. Global Ecology Biogeogr 13: 479-484

Scheiner SM, Cox SB, Willig M, Mittelbach GG, Osenberg C, Kaspari M (2000) Species richness, species-area curves and Simpson's paradox. Evol Ecol Res 2: 791-802

Scheiner SM, Jones S (2002) Diversity, productivity and scale in Wisconsin vegetation. Evol Ecol Res 4: 1097-1117 
Scheiner SM, Rey-Benayas JM (1994) Global patterns of plant diversity. Evol Ecol 8: 331-347 Schulze RE (1997) South African Atlas of Agrohydrology and - Climatology. Water Research Commission, Pretoria, Report TT82/96

Shmida A (1984) Whittaker's plant diversity sampling method. Israel J Bot 33: 41-46

Shmida A, Wilson MV (1985) Biological determinants of species diversity. J Biogeogr 12: 1-20

Smith GF, Hobson SR, Meyer NL, Chesselet P, Archer RH, Burgoyne PM, Glen HF, Herman PPJ, Retief E, Smithies SJ, Van Jaarsveld EJ, Welman WG (1993) Southern African succulent plants - an updated synopsis. Aloe 30: 32-74

Stirling G, Wilsey B (2001) Empirical relationships between species richness, evenness, and proportional diversity. Am Nat 158: 286-299

Stohlgren TJ, Falkner MB, Schell LD (1995) A modified-Whittaker nested vegetation sampling method. Vegetatio 117: 113-121

Tjørve E (2003) Shapes and functions of species-area curves: a review of possible models. J Biogeogr 30: 827-835

Van der Merwe H, Van Rooyen MW, Van Rooyen N (2008a) Vegetation of the HantamTanqua-Roggeveld subregion, South Africa. Part 1. Fynbos Biome related vegetation. Koedoe 50: 61-71

Van der Merwe H, Van Rooyen MW, Van Rooyen N (2008b). Vegetation of the HantamTanqua-Roggeveld subregion, South Africa. Part 2. Succulent Karoo Biome related vegetation. Koedoe 50: 161-183

Van Jaarsveld E (1987) The succulent riches of South Africa and Namibia. Aloe 24: 45-92

Van Wyk AE, Smith GF (Eds) (2001) Regions of Floristic Endemism in Southern Africa: A review with emphasis on succulents, pp. 1-199. Umdaus Press, Pretoria

Veech JA (2000) Choice of species-area function affects identification of hotspots. Conserv Biol 14: $140-147$

Vitousek PM, D'Antonio CM, Loope LL, Westbrooks R (1996) Biological invasions as global environmental change. Am Sci 84: 468-478

Weather Bureau (1998) Climate of South Africa. Climate statistics up to 1990. WB 42. Government Printer, Pretoria

Whittaker RH (1977) Evolution of species diversity on land communities. Evol Biol 10: 1-67 
Whittaker RJ, Willis KJ, Field R (2001) Scale and species richness: towards a general, hierarchical theory of species diversity. J Biogeogr 28: 453-470

Williams CB (1964) Patterns in the balance of nature. Academic Press, New York

Wilson MV, Shmida A (1984) Measuring Beta diversity with presence-absence data. J Ecol 72: $1055-1064$ 